\title{
Stay: Migration and the Caribbean Liane Chance
}

Liane Chance was born in Georgetown, Guyana and migrated to Barbados at age 11 and Toronto, Canada at 13. She has completed an Honours Bachelor of Arts at the University of Toronto, with a double major in History and Equity Studies. Liane has a particular interest in the educational experience of young Caribbean immigrants in Toronto and hopes to commence graduate studies related to the subject in the future.

Twentieth and twenty first century migration patterns have seen a large scale emigration from many Caribbean countries into Canada, the United States and the United Kingdom. This dispersion and settlement of Caribbean people into highly industrial parts of the world can be long-term, permanent or temporary. The primary motive for Caribbean migration has been the intent to improve economic circumstances, therefore migration out of the region persists when the perception of opportunities abroad outweigh the real opportunities at home. ${ }^{1}$ Migration rates from the Caribbean remain high and are steadily rising which indicates that the crumbling economic and social structures which sustain such rates continue to degrade. ${ }^{2}$ As a result, Caribbean countries continue to experience the loss of highly skilled men and women to more industrialized parts of the world. Therefore, the inability or failure to stem heavy outflows of labour hinders Caribbean development. 3 Recent trends have seen governments attempt to harness the financial wealth of their diasporas with the hope that the large number of residents abroad can set into motion and sustain a series of development initiatives. 4 In Jamaica, such strategies have involved tapping into the community abroad as well as encouraging emigration to create a larger capital remitting base. ${ }^{5}$ However, the framework for Jamaican diasporic development, which Patsy Lewis

\footnotetext{
1 Ransford W. Palmer, "Caribbean Development and the Migration Imperative," in In Search of a Better Life: Perspectives on Migration from the Caribbean ed. Ransford W. Palmer (New York, Connecticut, London: Praeger, 1990), 6

2 Barbara J. Merz, "Diasporic Engagement in the Caribbean," in Diasporas and Development ed. Barbara J. Merz et al. (Cambridge Massachusetts: Harvard University Press, 2007), 190

3 Palmer, 15

4 Merz, 204-211

5 Patsy Lewis, “Training Jamaicans for Export: A viable development strategy?" Unpublished Paper. (2003), 165
} 
calls "training-for-export," is problematic. To achieve any positive benefits for the Caribbean, people need to remain in the region. The solution seems simple but its implementation involves the cooperation and integration of elements of the Caribbean population both within the region and abroad. Development initiatives which involve or are spearheaded by the diaspora must follow a structured and logical plan. Encouraging migration out of the region is counterproductive, therefore the Caribbean must think regionally, rather than nationally, to implement tactics to improve the economic, social and political factors which push people out. Thirdly, the place of skilled return migrants must be examined.

Caribbean governments have known about the problem of emigration since the 1960s. The United Kingdom had been the traditional recipient of Caribbean migrants from 1948, but political shifts in Britain restricted Caribbean migration in the 1960s. As high unemployment and slow development plagued newly independent governments they encouraged the migration of unskilled labour to Canada and the United States, countries that had liberalized their immigration laws. ${ }^{6}$ The benefits of this strategy were lower unemployment levels, social stability, population control due to lower birth rates and remittances from the receiving countries to provide benefits for young and older family members.7 As the Caribbean moved into the latter decades of the $20^{\text {th }}$ century and the first years of the $21^{\text {st }}$, migration and the attitudes toward the trend have been characterized by much continuity and little change.

Between 1965, when immigration first began to increase, and 2000, the Caribbean region had seen over $12 \%$ of its labour force migrate to more developed countries such as the United States and Canada. ${ }^{8}$ Countries such as Jamaica and Guyana experienced far higher rates of emigration with Jamaica losing $85 \%$ of its educated labour force in the same period. 9 Understanding that migration is an intrinsic and sustained Caribbean character trait and also aware of the value of remittances sent back by residents working and living

\footnotetext{
6 Ralph Henry and Kim Johnson, "Migration, Manpower, and Underdevelopment of the Commonwealth Caribbean," in Migration and Development in the Caribbean: The Unexplored Connection ed. Robert A. Pastor (Boulder, Colorado: Westview Press Inc, 1985), 279.

7 Henry, 279

8 Lewis, 166

9 Patsy Lewis, 166
} 
abroad, Caribbean governments have entertained the idea of making migration work to their advantage. ${ }^{10}$ However, the present framework for the distribution of remittances contributes to unequal benefits for residents of the Caribbean. Development strategies rooted in the diaspora must operate within an equitable framework.

Compared to the Anglophone Caribbean, migration in Cuba had long been an instrument of national policy and was relied upon to accumulate capital for the state and also to create blocs of influence in other parts of the world. ${ }^{11}$ However, in Cuba government sanctioned migration is a controlled policy which eventually results in the repatriation of skilled labour. ${ }^{12}$ Recent trends attributed to "political and geo-strategic shifts" in the "international trading environment," have had a hand in altering the way Caribbean governments have perceived emigration. ${ }^{13}$ Lewis' observation of the Jamaican government's view of migration places it in a similar framework to that which Robert Pastor and Rosemarie Rogers identified as Cuba's migration policy. In Lewis' analysis emigration was considered beyond its obvious effects of draining labour and enterprise from the country and reworked by the government to see the outflow of people from the country as a "potential tool."14 Lewis' work did not identify a governmental strategy for the repatriation of labour but it did posit the remittance of capital from educated migrants as a salient strategy to bring foreign capital into the country. However, if diasporas are to be utilized as a development strategy the capital sent back must flow in ways to benefit the entire country.

Currently, remittances, other than those sent by regulated temporary workers, go directly to the intended recipient, there is no benefit to the country as a whole because the capital is used to better

\footnotetext{
10 Robert Pastor and Rosemarie Rogers, "Using Migration to Enhance Economic Development in the Caribbean: Three Sets of Proposals," in Migration and Development in the Caribbean: The Unexplored Connection ed. Robert A. Pastor (Boulder, Colorado: Westview Press Inc, 1985), 321; Elizabeth Thomas-Hope, Caribbean Migration (Barbados, Jamaica, Trinidad and Tobago: University of the West Indies Press, 2002), 160

11 Pastor, 321

12 Pastor, 321

13 Lewis, 169

14 Lewis, 169
} 
the circumstances of that recipient. ${ }^{15}$ Also important is the fact that remittances can serve to reduce governmental responsibility to citizens' welfare because beneficiaries may accrue enough capital to bypass public services in preference of private ones. ${ }^{16}$ They can also contribute to further emigration from the receiving country as it provides improved access to education. Generally, remittances are unequally accessed by receiving populations - therefore its overall poverty reducing effects are questionable if the current framework continues because the practice has a high number of individual beneficiaries. ${ }^{17}$

Recent tabulations of remittances flowing through official avenues have indicated that the countries in the Caribbean receive anywhere from 100 million to 1.4 billion dollars in remittances every year. ${ }^{18}$ The actual amount of capital, however, is rarely ever the amount received by the recipient. According to research done on the topic of fair value, a transaction can cost up to $25 \%$ of the amount being sent due to factors such as commissions, exchange rates and transaction fees. ${ }^{19}$ In their articles, Robert Pastor, Rosemarie Rogers and Wilbert Bascom suggest that the Caribbean region establish remittance banks to take over the position of money transmission businesses. ${ }^{20}$ This would have the effect of actually giving Caribbean governments a certain amount of capital earned from transmitting remittances at a better and more competitive rate. The recipients would continue to receive money from their relatives while governments would have the ability to take the capital accrued and reinvest it into development schemes as well as ease balance of

\footnotetext{
15 Wilbert O. Bascom, "Remittance Inflows and Economic Development in Selected Anglophone Caribbean Countries," in Migration, Remittances and Small Business Development ed. Sergio Diaz-Briquets et al. (Colorado: Westview Press Inc., 1991), 77

16 Merz, 206

17 Admos Chimhowu et al, "The Socioeconomic Impact of Remittances on Poverty Reduction," in Remittances: Development Impact and Future Prospects ed. Samuel Munzele Maimbo et al (Washington, DC: World Bank, 2005), 94-95

18 Merz, 190

19 Norbert Bielefeld and Antonique Koning, "International Remittances: Delivering Fair Value," in Remittances: Development Impact and Future Prospects ed. Samuel Munzele Maimbo et al. (Washington, DC: World Bank, 2005), 194

20 Bascom, 90-91; Pastor, 333-336.
} 
payment debts in the region. ${ }^{21}$ Ultimately, a Caribbean remittance bank would encourage the development of the country or region by stimulating the economy enough to provide incentive for labour to remain or return to the country.

The strategy Patsy Lewis identified in her essay was that of "training-for-export" programs. As mentioned above, the Jamaican government as with others in the region does not infringe on the rights of their people to migrate but the result has been that the country has long suffered with the emigration of its skilled labour. ${ }^{22}$ It must also be noted that the type of emigrating labour is subject to a hierarchy where highly skilled labour is considered intrinsic to development, while cheaper labour emigration was encouraged to ease unemployment rates. ${ }^{23}$ In a strategy which prioritized Elizabeth Thomas-Hope's theory that migration builds and recreates the Caribbean, the Jamaican government "advocated" its "training for export" strategy. 24 The idea was to invest in the training of nurses and teachers with the intent that eventually these women, and to a lesser extent men, would migrate abroad and remit capital to the sending country, Jamaica. ${ }^{25}$ However, Lewis was hard-pressed to find the wisdom in this strategy, especially since the statistics indicate that Caribbean governments spend far more on education than they recover from remitted capital. ${ }^{26}$ "Training for export" and other development strategies which incorporated education or training turned out to benefit the economy of the receiving country while the sending Caribbean country struggled to cope with the loss of labour and a dubious return on investment. ${ }^{27}$ The strategy of

\footnotetext{
21 Pastor, 334-335; Michele Reis, "The Modern to Late Period in the Caribbean Diaspora," in Caribbean Transnationalism: Migration, Pluralization and Social Cohesion ed. Ruben Gowricharn. (Lanham: Lexington Books, 2006), 52

22 Patricia Y. Anderson, "Migration and Development in Jamaica," in Migration and Development in the Caribbean: The Unexplored Connection ed. Robert A. Pastor (Boulder, Colorado: Westview Press Inc, 1985), 120.

23 Anderson, 121

24 Thomas-Hope, Caribbean Migration, 160

25 Lewis, 175

26 Elizabeth Thomas-Hope, "Return Migration and Its Implications for Caribbean Development," in in Migration and Development in the Caribbean: The Unexplored Connection ed. Robert A. Pastor (Boulder, Colorado: Westview Press Inc, 1985), 167; Lewis, 169.

27 Ralph Henry and Kim Johnson, "Migration, Manpower and the Underdevelopment of the Commonwealth Caribbean," in Migration and
} 
"training for development" rings counterproductive to any strategy that is to empower the Caribbean region since skilled labour is integral to the development of the region. The issue remains providing skilled Caribbean people with enough incentive to remain in the region.

The concept of the brain drain has long accompanied discourses on Caribbean emigration. The drain has been the result of unfavourable economic climates and it has also contributed to this effect. Instead of focusing on creating incentives to return, countries such as Jamaica, have encouraged labour to leave because of the purported level of remittances their absence brings. ${ }^{28}$ Caribbean countries uphold their citizen's right to migrate freely but have historically oriented migration outside the region rather than taking an active role to foster intraregional migration. As an alternative to sending trained individuals outside of the region, Lewis examined propositions to allow the free movement of these individuals from country to country. ${ }^{29}$ Intraregional migration of nurses and teachers would have the effect of keeping labour within the region by deploying these men and women to countries which experienced chronic shortage of teachers and nurses. 30

Palmer also views intraregional migration as a plausible and desirable alternative to flows outside of the region. He argues that the Caribbean as a region needs to expand and diversify its productive industries and implement a "common market agreement" which does not restrict labour flows. ${ }^{31}$ In short, Caribbean countries need to form a structured economic bloc to move beyond single market economies in order for the region to decrease its vulnerability to the vagaries of the economic market. ${ }^{2}$ Palmer's prescriptions are not new ideas, as the idea of integration and diversified economies has been debated and attempted in the region on previous occasions, the most recent incarnation being the formation of CARICOM. ${ }^{3}$

\footnotetext{
Development in the Caribbean: The Unexplored Connection ed. Robert A. Pastor (Boulder, Colorado: Westview Press Inc, 1985), 281

28 Lewis, 169

29 Lewis, 178

30 Lewis, 178

31 Palmer, 13-14

32 Palmer, 14

33 Peter Wickman, "Factors in the Integration and Disintegration of the Caribbean," in Introduction to Caribbean Politics ed Cynthia Barrow-Giles, (Ian Randle Publishers, 2002.)
} 
Freedom of movement policies were being considered in the early 1990 s but were waylaid by countries that feared being overrun by migrants who wished to access the better economic conditions of that society. 34 The saliency of integration as a way to retain migrants in the region is impossible to ignore, and the re-examination of the strategy by Caribbean governments bodes well for the development of the region's economy for the purposes of retaining labour.

In her article on the developmental impacts of return migration on the Caribbean, Elizabeth Thomas-Hope surmises that it is difficult to tabulate the effect of the return migrant on the development of his or her country. Although the return may involve the influx of foreign capital, talent and skilled labour, Thomas-Hope argues that foreign lifestyles and products also return. This has the effect of stimulating the consumption of foreign products because the orientation of Caribbean households to foreign markets is sustained. 35 Thomas-Hope also argues that the short-term effects of return migration, which include the investment of capital into ventures such as housing or short-term participation in the labour force, often masquerade as positive indicators of development. ${ }^{6}$

Thomas-Hope's pessimistic analysis ignores the other side of the return movement however, namely the growing amount of people whose intentions to return are focused entirely on the development of the region. In their article on return migration to Grenada, Joseph Rodman and Dennis Conway highlight the nostalgic and nationalistic factors which propel migrants settled abroad to return. ${ }^{37}$ Many of these migrants have been educated abroad and seek to impart their skills to effect development within their countries..$^{8}$ Therefore it follows that the Caribbean region must provide a framework which supports return migrants who have either business or education initiatives which serve to improve the region by creating employment or providing specialized skills to the labour force.

\footnotetext{
34 Wickman, 246

35 Thomas-Hope, "Return Migration,"172

36 Thomas-Hope, "Return Migration," 172

37 Dennis Conway and Joseph Rodman, "The Nexus and the Family Tree: Return Migration to Grenada and Transnationalism in Context," in The Experience of Return Migration: Caribbean ed. Robert B. Potter et al. (Aldershot, England, Burlington, Vermont: Ashgate, 2005), 101

38 Conway, 101
} 
Migration created the Caribbean and migration recreates the Caribbean. ${ }^{39}$ It is the constant force that the region cannot ignore, however it should not be viewed as a solution to socioeconomic issues in the Caribbean. Although not addressed in the above analysis, migration accounts for the weakening of family structures as migrants sacrifice familial ties to provide monetary support for spouses, parents and children back home. Some migrants also face alienation, racism and prejudice as they navigate the maze of a foreign society. Migration will always occur but it is imperative that the region implement more insular techniques to address its weaknesses and rely upon Caribbean people, ideas and initiatives to create better opportunities for future generations and also to retain and regain its people.

39 Thomas-Hope, Caribbean Migration, 160 